\title{
DENSITY ZOOXANTHELLA BASED ON THE LIFE FORM OF CORAL ON MARAK ISLAND WEST SUMATERA PROVINCE
}

\author{
Lieng Lieng*1, Efriyeldi ${ }^{2}$, Thamrin ${ }^{2}$ \\ ${ }^{1}$ Student of the Faculty of Fisheries and Marine Universitas Riau, Pekanbaru \\ ${ }^{2}$ Lecturer at the Faculty of Fisheries and Marine Universitas Riau, Pekanbaru \\ *lienglieng80@gmail.com
}

\begin{abstract}
This study aims to determine differences in zooxanthella density based on the life forms of coral Acropora Branching, Submassive Acropora, Branching, Foliose, Heliopora and comparing zooxanthella densities between the forms of coral form. This study was conducted in January-February 2020 on Marak Island, Nagari Sungai Pinang, West Sumatera Province. Zooxanthella density was calculated at the Marine Biology Laboratory, Department of Marine Sciences, University of Riau. The survey methode was used in this study, where the data collected was primary data. Coral Sampling was done by free collection using the SCUBA (Self Contained Underwater Breathing Apparatus). The result of study in the waters of Marak Island, West Sumatera on Acropora Branching corals were in the range of 0.004$0.13 \times 10^{6}$ cells $/ \mathrm{cm}^{2}$. Acropora Submassive range of $2.95-3.56 \times 10^{6}$ cells $/ \mathrm{cm}^{2}$. Branching range of $2.41-2.59 \times 10^{6}$ cells $/ \mathrm{cm}^{2}$. Foliose range of $0.44-1.09 \times 10^{6}$ cell $/ \mathrm{cm}^{2}$. Heliopora range of $1.30-1.59 \times 10^{6}$ cell $/ \mathrm{cm}^{2}$. The highest zooxanthella density was in Submassive Acropora and the lowest in Acropora Branching corals due to different forms of growth and temperature influences. Different forms of coral growth affect the zooxanthella density on a coral and the success of coral growth depends on the zooxanthella density and the size of the corallite of each coral life form.
\end{abstract}

Keywords: Coral, density, life form coral, zooxanthella, Marak Island.

\section{PENDAHULUAN}

Terumbu karang tersebar luas di perairan Indonesia, salah satunya tersebar di wilayah Kawasan Teluk Mandeh yang terletak di Kecamatan Koto XI Tarusan Kabupaten Pesisir Selatan, Provinsi Sumatera Barat. Terdapat beberapa Pulau dikawasan Mandeh yakni Pulau Taraju, Pulau Setan atau Sutan, Pulau Sironjong besar, Pulau Sironjong Ketek, Pulau Kapokapo, Sungai Nyalo, Pulau Cubadak dan Pulau Marak. Pualu Marak merupakan pulau tidak berpenghuni dan jauh dari aktifitas masyarakat dan nelayan, sehingga perairan Pulau Marak memiliki kondisi yang alami, jernih dan jauh dari penyebab pencemaran. Peraiaran ini memiliki potensi perikanan dan kelautan yang bagus seperti terumbu karang. Berdasarkan Frananda et al., (2019) kualitas perairan pada Kawasan Mandeh sangat baik dan cocok untuk mendukung kehidupan pertumbuhan terumbu karang.

Terumbu karang memiliki fungsi sebagai pelindung pantai dari degradasi dan abrasi. Pertumbuhan karang yang baik ditandai dengan adanya zooxanthella yang bersimbiosis pada karang. Menurut Asmiati et al. (2017) hubungan mutualisme terjadi antara dua makhluk hidup ini. Zooxanthella 
hidup di dalam lapisan endodermis, lapisan sel bagian dalam pada karang yang kehadirannya sangat berperan penting bagi kelangsungan hidup karang, diantaranya berperan dalam proses pembentukan terumbu atau kalsifikasi.

Secara umum jumlah zooxanthella yang terkandung pada polip terumbu karang normal adalah berkisar antara 0,23$1,75 \times 10^{6} \mathrm{sel} / \mathrm{cm}^{2}$ (Costa dan Amaral, 2000). Selain itu menurut Thamrin (2017) bahwa jumlah zooxanthella yang melimpah di dalam jaringan karang menyebabkan kecepatan pertumbuhan karang dan warnanya akan semakin gelap dengan semakin tingginya pigmen zooxanthella. Kecepatan pertumbuhan karang bervariasi dan tergantung bentuk koloni.

Bentuk pertumbuhan karang berbeda-beda diantaranya bentuk Acropora dan non-Acropora, Hal ini mempengaruhi densitas zooxanthella pada suatu karang dan keberhasilan pertumbuhan karang tergantung pada densitas zooxanthella. Berdasarkan pemaparan tersebut, peneliti ingin melakukan penelitian mengenai densitas zooxanthella pada lima tipe life form karang untuk mengetahui karakteristik dan perbedaan densitas zooxanthella berdasarkan bentuk pertumbuhan karang Acropora Branching, Acropora Submassive, Branching, Foliose, dan Heliopora.

\section{METODE PENELITIAN Waktu dan Tempat}

Penelitian ini dilaksanakan pada 20 Januari di Pulau Marak, Nagari Sungai Pinang, Provinsi Sumatera Barat (Gambar 1) dan dilanjutkan hingga Februari 2020 untuk perhitungan densitas Zooxhantella di Laboratorium Biologi Laut Jurusan Ilmu Kelautan Universitas Riau.

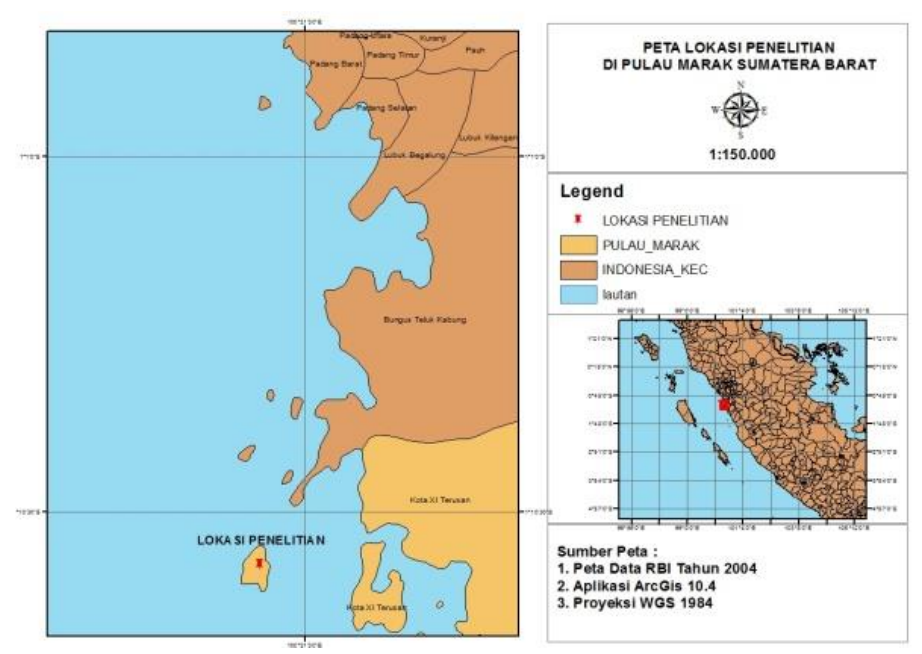

Gambar 1. Peta Lokasi Penelitian

\section{Metode Penelitian}

Metode yang digunakan pada penelitian ini adalah metode survei, untuk pengambilan sampel karang menggunakan teknik purposive sampling berdasarkan bentuk pertumbuhan karang. di kedalaman 6 meter. Karang jenis Acropora Submassive, Branching, Foliose dan Heliopora diambil pada titik sampling pertama. Pada titik sampling kedua diambil karang jenis Acropora Branching. Koloni karang yang sehat dijadikan obyek dengan asumsi masih banyak terdapat zooxanthella pada karang tersebut. Koloni karang yang diambil merupakan karang yang diamati menggunakan coral health chart.

\section{Prosedur Penelitian}

Pengambilan sampel karang dilakukan dengan koleksi bebas (free 
handpicking) berdasarkan Gaffar dan Purwanti (2014) dengan menggunakan alat bantu SCUBA (Self Contained Underwater Breathing Apparatus). Fragmen karang diambil sebanyak 11 kali pengulangan pada masing-masing bentuk pertumbuhan. Pengambilan sampel biota karang dilakukan dengan menggunakan tang kakak tua (tang gegep) dan palu yaitu dengan mengambil bagian dari koloni karang yang mewakili bentuk pertumbuhan karang, untuk karang bentuk bercabang diukur dengan panjang $4 \mathrm{~cm}$, dan untuk karang yang memiliki bentuk seperti lembaran berukuran $4 \times 4 \mathrm{~cm}$. Untuk perlakuan pada sampel karang merujuk pada Thamrin (1994) yaitu, koloni yang diambil difiksasi dalam $100 \mathrm{ml}$ air laut dan diberi formalin (10\%) $1 \mathrm{ml}$. Proses fiksasi ini dilakukan selama 24 jam. Kemudian sampel dibawa ke laboratorium. Setelah ukuran panjang serta diameter sampel diukur, sampel didekalsifikasi dalam larutan formalin $(5 \%)$ $75 \mathrm{ml}+$ asam asetat (5\%) $75 \mathrm{ml}$ selama 16 hari. Tisu yang telah didekalsifikasi terpisah dari skeletonnya kemudian dicuci selama 24 jam.

Pencucian tisu karang dilakukan dengan meletakkan sampel ke dalam kantong kain kasa, dan direndam di dalam ember yang memiliki volume 3 liter air yang dialiri dengan air keran (air tawar) untuk menghilangkan asam asetat dan formalin. Setelah selesai, tisu (sampel) ini disimpan di dalam $1 \mathrm{ml}$ alkohol (70\%) untuk menghindari kerusakan. Selanjutnya tisu karang di gerus sampai halus dengan alat didalam cawan kecil, setelah tisu karang halus dimasukkan ke dalam gelas ukur dan ditambahkan aquades sebanyak $15 \mathrm{ml}$, kemudian sampel diaduk rata. Subsampel yang diamati diambil menggunakan pipet tetes dan diteteskan diatas haemacytometer dan ditutup dengan cover glass, untuk pencacahan dan dihitung dibawah mikroskop binokuler menggunakan perbesaran $10 \times 10$ dengan tiga kali ulangan untuk tiap cabang karang.
Perhitungan densitas zooxanthella menggunakan rumus sebagai berikut (Effendi dan Aunurohim, 2012):

$\begin{array}{ll}\mathrm{D} & : \begin{array}{l}\text { Densitas Zooxanthella } \\ \left(\mathrm{sel} / \mathrm{cm}^{2}\right)\end{array} \\ \mathrm{Q} & : \begin{array}{l}\text { Jumlah Zooxanthella yang } \\ \text { terhitung (sel) }\end{array} \\ \mathrm{P} & : \begin{array}{l}\text { Volume sampel }(\mathrm{ml}) \\ \mathrm{L}\end{array}: \begin{array}{l}\text { Luasan Fragmen Karang }\left(\mathrm{cm}^{2}\right) \\ 10000:\end{array} \\ & \begin{array}{l}\text { Konversi } 0,1 \mathrm{~mm}^{3} \text { menjadi } 1 \\ \mathrm{~mm}^{3}\end{array}\end{array}$

Hasil perhitungan sel kemudian ditabulasi dan dideskripsikan dengan bantuan grafik serta dibahas secara deskriptif. Untuk melihat perbedaan densitas zooxanthella berdasarkan bentuk pertumbuhan karang dilakukan uji One Way ANOVA dan dilanjutkan dengan uji Lanjut Tukey untuk melihat perbedaan antar bentuk pertumbuhan.

\section{HASIL DAN PEMBAHASAN Keadaan Umum Daerah Penelitian}

Pulau Marak merupakan salah satu pulau yang berada di kawasan Teluk Mandeh, tepatnya di Nagari Sungai Pinang, Kecamatan Koto XI Tarusan Kabupaten Pesisir Selatan Provinsi Sumatera Barat Pulau ini memiliki luas $500 \mathrm{Ha}$ dan berjarak $36 \mathrm{Km}$ dari Ibukota Kabupaten. Pulau Marak merupakan salah satu pulau yang berhadapan dengan Samudera Hindia, memiliki pasir putih dan tidak berpenghuni menjadikan perairan di pulau ini sangat alami dan dijuluki The Paradise in the South.

\section{Kondisi Lingkungan Perairan Pulau Marak}

Hasil pengukuran parameter oseanografi pada penelitian yaitu Perairan Pulau Marak memiliki suhu $32{ }^{\circ} \mathrm{C}$, salinitas $30 \%$, pH 8.3, kecepatan arus $0,06 \mathrm{~m} / \mathrm{s}$, kedalaman 6 meter dan kecerahan $100 \%$. Perubahan suhu dapat menyebabkan fenomena coral bleaching. Suhu perairan di 
pulau Marak yaitu $32^{\circ} \mathrm{C}$ tersebut masih dapat ditolerir oleh karang. Seperti menurut Suharsono (2010) kisaran suhu yang masih dapat ditoleransi oleh karang yang hidup diperairan Indonesia berkisar antara 26$34^{\circ} \mathrm{C}$.

Nybakken (1992) menyatakan bahwa terumbu karang sangat sensitif terhadap perubahan salinitas yang lebih tinggi atau lebih rendah dari salinitas normal, yaitu 30$35 \%$. Pulau Marak memiliki salinitas sebesar $30 \%$ menandakan bahwa salinitas di Pulau Marak tergolong dalam salinitas yang masih normal. pengukuran $\mathrm{pH}$ pada penelitian ini adalah 8,3. Tomascik et al. dalam Luthfi dan Anugrah (2017) yang menyatakan habitat yang cocok bagi pertumbuhan karang adalah yang memiliki $\mathrm{pH}$ antara 8,2 - 8,5.

Kedalaman 6 meter merupakan kedalaman yang baik untuk pertumbuhan karang seperti yang dinyatakan oleh Thamrin (2017) bahwa pertumbuhan terbaik pada kedalaman antara 3 hingga 10 meter. Kondisi yang baik menurut KEPMEN LH 2004, kecerahan yang baik bagi kehidupan terumbu karang adalah $>5$ meter. Kecerahan pada lokasi pengambilan sampel adalah $100 \%$. Hal ini menandakan bahwa kecerahan masih menembus kedalaman 6, dan ini selalu berkaitan dengan simbion karang yang memerlukan cahaya matahari untuk berfotosintesis.

\section{Karakteristik Zooxanthella}

Karakteristik zooxanthella pada penelitian ini ditemukan zooxanthella berwarna kuning keemasan dan kuning kehijauan. Warna kuning keemasan ditemukan pada empat bentuk pertumbuhan karang yaitu Acropora Branching, Branching, Foliose dan Heliopora. Sedangkan pada karang Acropora Submassive berwarna kuning kehijauan.

Hasil penelitian ini memiliki perbedaan dengan penelitian yang dilakukan sebelumnya oleh Affandi (2015) zooxanthella pada karang jenis Acropora Branching memiliki zooxanthella berwarna kuning kehijauan. Menurut Fahn dalam Ain (2019) warna kuning kehijauan pada sel yang diamati disebabkan oleh kloroplas yang tampak tersebar di dalam sel. Fungsi kloroplas adalah tempat penyimpanan pigmen klorofil sebagai tempat berlangsungnya proses fotosintesis.

Zooxanthella yang diamati di laboratorium merupakan zooxanthella yang berada pada fase kokoid yaitu fase zooxanthella berada di dalam jaringan inang. Zooxanthella memiliki dua fase daur hidup yaitu fase motil dan fase kokid. Ira (2004) menyatakan bahwa sel dapat bergerak bebas di kolom perairan berada pada fase motil. Fase kokoid adalah fase dimana zooxanthella berada di dalam jaringan inang. Keberadaan zooxanthella di dalam tubuh karang menyebabkan karang memiliki warna, semakin gelap warna karang menandakan zooxanthella yang terkandung pada karang semakin tinggi.

\section{Densitas Zooxanthella Pada Berbagai Bentuk Pertumbuhan Karang}

Hasil perhitungan densitas

zooxanthella pada berbagai bentuk pertumbuhan yaitu Acropora Branching, Acropora Submassive, Branching, Foliose dan Heliopora dapat dilihat pada Tabel 1. Berdasarkan Gambar 2 dapat dilihat bahwa densitas zooxanthella pada karang jenis Acropora Submassive memiliki densitas tertinggi, Acropora Branching memiliki jumlah paling rendah dibandingkan yang lainnya.

Berdasarkan hasil pengamatan, bentuk pertumbuhan karang yang berbeda memiliki pengaruh yang signifikan terhadap densitas zooxanthella dapat dilihat dari hasil uji ANOVA menunjukkan nilai signifikan sebesar 0,000 pada $\mathrm{P}<0,05$ dan berdasarkan uji lanjut Tukey diperoleh bahwa antar bentuk pertumbuhan berbeda nyata. 
Tabel 1. Rata-rata jumlah densitas zooxanthella

\begin{tabular}{llll}
\hline No & $\begin{array}{l}\text { Bentuk Pertumbuhan } \\
\text { Karang }\end{array}$ & $\begin{array}{l}\text { Rata-Rata Jumlah Densitas } \\
\text { Zooxanthella }\left(\times \mathbf{1 0}^{\mathbf{6}} \mathbf{s e l} / \mathbf{c m}^{\mathbf{2}}\right)\end{array}$ & $\begin{array}{l}\text { Standar } \\
\text { Deviasi }\end{array}$ \\
\hline 1 & Acropora Branching & 52.328 & 43955.40281 \\
2 & Acropora Submassive & 3.253 .668 & 209409.5667 \\
3 & Branching & 2.512 .270 & 59716.6176 \\
4 & Foliose & 893.744 & 227320.7 \\
5 & Heliopora & 1.315 .728 & 97661.838 \\
\hline
\end{tabular}

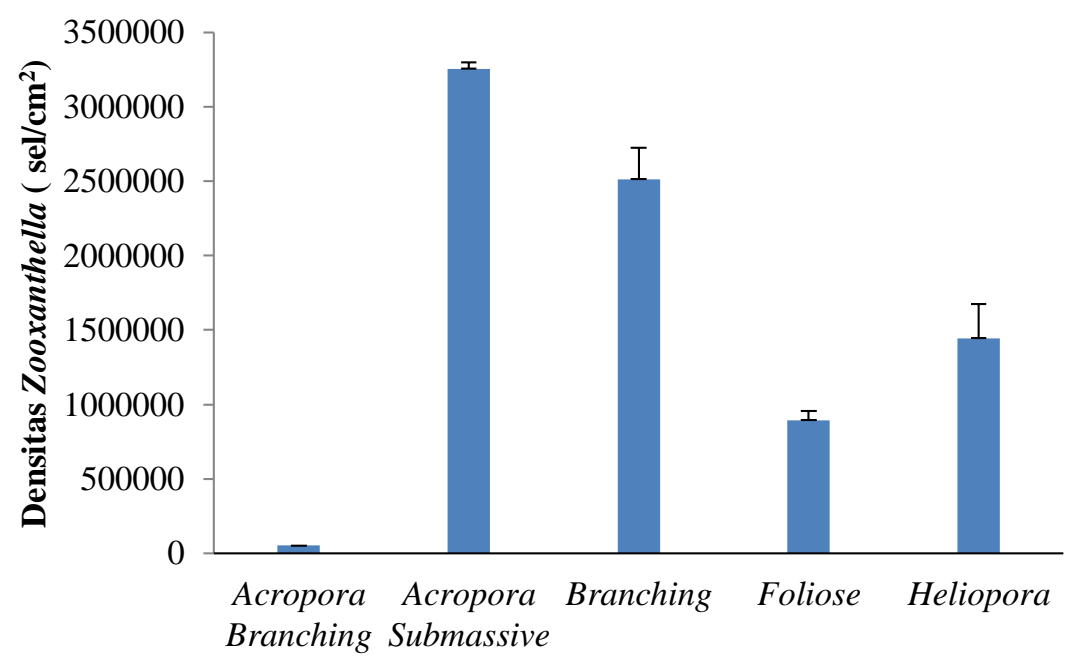

Bentuk Pertumbuhan Karang

Gambar 2. Rata-rata jumlah densitas zooxanthella $\left(\times 10^{6} \mathrm{sel} / \mathrm{cm}^{2}\right)$

Berdasarkan hasil pengamatan di perairan Pulau Marak, Sumatera Barat pada karang Acropora Branching berada dalam kisaran $0,004-0,13 \times 10^{6} \mathrm{sel} / \mathrm{cm}^{2}$. Acropora Submassive kisaran $2,95-3,56 \times 10^{6} \mathrm{sel} / \mathrm{cm}^{2}$. Branching kisaran $2,41-2,59 \times 10^{6} \mathrm{sel} / \mathrm{cm}^{2}$. Foliose kisaran $0,44-1,09 \times 10^{6} \quad \mathrm{sel} / \mathrm{cm}^{2}$. Heliopora kisaran $1,30-1,59 \times 10^{6} \mathrm{sel} / \mathrm{cm}^{2}$.

Karang normal berdasarkan Costa dan Amaral (2000) memiliki zooxanthella $0,23-1,75 \times 10^{6} \mathrm{sel} / \mathrm{cm}^{2}$ dan Drew dalam Wilkerson et al. (1988) menyatakan densitas zooxanthella mencapai $8,5 \times 10^{6}$ $\mathrm{sel} / \mathrm{cm}^{2}$ pada permukaan karang, dimana tergantung spesies dan kedalaman habitatnya. Secara tidak langsung kedalaman mempengaruhi densitas zooxanthella, karena semakin dalam suatu perairan maka cahaya yang diterima semakin sedikit. Cahaya dibutuhkan oleh zooxanthella untuk proses fotosintesis.
Pada penelitian ini kecerahan perairan Pulau Marak adalah $100 \%$ sedangkan koloni karang diambil pada kedalaman 6 meter. Berdasarkan nilai kecerahan tersebut, sangat mendukung cahaya matahari untuk masuk ke perairan sehingga dapat dimanfaatkan oleh algae simbion karang untuk berfotosintesis agar kebutuhuan nutrisi karang terpenuhi. Bentuk pertumbuhan yang berbeda-beda memberi pengaruh terhadap densitas zooxanthella pada masing-masing karang dikarenakan bentuk pertumbuhan mempengaruhi penyerapan cahaya oleh simbion karang.

Bentuk pertumbuhan karang jenis Acropora Submassive tumbuh membentuk pilar-pilar dan memiliki jarak yang lebar antara cabang satu dengan yang lain. Densitas zooxanthella tertinggi diperoleh pada Acropora Submassive yaitu 3,56×10 
$\mathrm{sel} / \mathrm{cm}^{2}$ dan terendah pada karang Acropora Branching yaitu $0,0043 \times 10^{6} \mathrm{sel} / \mathrm{cm}^{2}$. Karena Acropora Submassive memiliki ukuran corallite yang lebih besar dibandingkan Heliopora, Foliose dan Branching. Berdasarkan Kelley (2009) jenis karang Acropora memiliki ukuran coralite $2 \mathrm{~mm}$, Branching 0,8 - 1,5 mm, Heliopora $1 \mathrm{~mm}$, dan Foliose berukuran < $0,5 \mathrm{~mm}$. Berdasarkan penelitian yang dilakukan oleh Fachrurrozie (2012) bahwa kelimpahan zooxanthella pada karang memiliki korelasi yang kuat dengan diameter corallite pada karang itu sendiri. Sebanding dengan hasil penelitian yang dilakukan, Acropora Submassive memiliki densitas yang lebih tinggi dari 3 bentuk karang normal lainnya.

Sedangkan heliopora, dan foliose tidak memiliki percabangan. Karakter yang berbeda tersebut mempengaruhi penyerapan cahaya yang akan dimanfaatkan oleh algae simbion karang yaitu zooxanthella. Karang yang memiliki percabangan lebih optimum mendapatkan sinar matahari karena semua cabang memungkinkan untuk menyerap cahaya dibandingkan heliopora yang berbentuk pipih dan memiliki jarak yang rapat antar koloni, sehingga menghambat penerimaan cahaya antar koloni sama seperti karang jenis foliose.

Karang jenis Foliose memiliki bentuk lembaran tipis sehingga memungkinkan ruang yang lebih sempit bagi zooxanthella untuk hidup. Bentuk lembaran menyebabkan karang cenderung tertutup oleh endapan sedimentasi. Tertutupnya hewan karang oleh endapan sedimen, mengakibatkan zooxanthella tidak dapat menerima cahaya dengan maksimal untuk memenuhi kebutuhan nutrisi karang, oleh karena itu karang jenis ini memiliki densitas zooxanthella yang lebih rendah dari 3 jenis karang normal lainnya. Hasil penelitian ini sebanding dengan penelitian sebelumnya yang dilakukan oleh Asmiati (2017) bahwa Foliose memiliki jumlah rata-rata densitas zooxanthella paling rendah dibandingkan dengan bentuk lainnya yaitu $0,27 \times 10^{6} \mathrm{sel} / \mathrm{cm}^{2}$ dengan kisaran $0,19-1,60 \times 10^{6} \mathrm{sel} / \mathrm{cm}^{2}$.

Acropora Branching dan Branching memiliki bentuk percabangan. Berdasarkan dari hasil penelitian yang telah dilakukan Acropora Branching memiliki densitas paling rendah. Hasil dari penelitian ini berbanding terbalik dengan penelitian yang dilakukan oleh Lakastri et al. (2018) bahwa Acropora Branching memiliki densitas yang lebih tinggi dari karang jenis Branching. Selain itu, hasil penelitian ini juga pada penelitian sebelumnya yang dilakukan oleh Asmiati et al. (2017) yaitu rata-rata densitas zooxanthella tertinggi pada Acropora Branching. Hal serupa juga ditemukan pada hasil penelitian Fachrurrozie (2012) juga menyatakan bahwa tipe life form Acropora Branching memiliki kandungan zooxanthella lebih banyak $\left(0,5-1,3 \times 10^{6} \mathrm{sel} / \mathrm{cm}^{2}\right)$ dari karang jenis Mentipora. Perbedaan tersebut karena dilihat dari bentuk morfologi karang Acropora Branching memiliki axial dan radial corallite sehingga memungkinkan penyerapan cahaya lebih banyak dari bentuk karang yang lainnya. Berdasarkan Reid et al. (2011) tonjolan-tonjolan kecil dan memiliki banyak percabangan pada karang jenis Acropora Branching sehingga memungkinkan ruang untuk zooxanthella hidup lebih banyak.

Perbedaan ini disebabkan oleh fenomena coral bleaching yang terjadi pada Acropora Branching. Sehubungan dengan suhu Perairan Pulau Marak dapat dilihat pada tabel 3 yaitu $32{ }^{\circ} \mathrm{C}$ melebihi suhu optimum untuk perkembangan zooxanthella mengakibatkan keluarnya zooxanthella dari polip karang yang mengakibatkan bleaching, memudarnya warna karang. Berdasarkan Manuputty (2008) bahwa zooxanthella dapat tumbuh optimum pada suhu $26-28^{\circ} \mathrm{C}$. Hal ini disebabkan karena Acropora Branching lebih rentan terhadap perubahan suhu. 
Seperti pendapat Johan (2007) Acropora Branching memiliki kelemahan yaitu rentan terhadap tekanan yang berasal dari lingkungan. Jenis karang dari kelompok Acroporoid sangat sensitif dan tidak dapat bertahan ketika terjadi kenaikan suhu, sedangkan karang-karang porites dan yang memiliki ukuran polip besar biasanya lebih tahan terhadap kenaikan suhu (Coremap, 2020). Sehubungan dengan pendapat Asmiati et al. (2017) menyatakan kesempatan untuk bertahan hidup bervariasi pada masing masing jenis.

Karang yang diteliti memiliki zooxanthella clade $\mathrm{C}$ karena clade $\mathrm{C}$ dapat ditemukan di perairan dangkal, selain itu beberapa clade $\mathrm{C}$ lebih sensitif terhadap temperatur yang tinggi. Oleh karena itu Acropora Branching mengalami bleaching. Namun beberapa jenis clade $\mathrm{C}$ juga tahan terhadap suhu yang tinggi penyebab bleaching. Pendapat serupa juga dinyatakan oleh LaJeunesse et al. dalam Thamrin (2017) beberapa tipe C menunjukkan menjadi tahan terhadap bleaching. Oleh karena itu beberapa jenis karang lainnya memiliki densitas zooxanthella dalam kategori normal dan lebih tinggi dibandingkan Acropora branching.

\section{KESIMPULAN DAN SARAN}

Bentuk pertumbuhan karang yang diamati di perairan Pulau Marak yaitu Acropora Submassive, Acropora Branching, Branching, Foliose dan Heliopora. Warna zooxanthella pada jenis karang Acropora Branching, Branching, Foliose dan Heliopora memiliki karakteristik berbentuk bulat, berwarna kuning keemasan dan kuning kehijauan pada Acropora Submassive. Densitas tertinggi yaitu pada karang Acropora Submassive dan terendah pada karang Acropora Branching, masing-masing bentuk pertumbuhan karang mempunyai perbedaan densitas zooxanthella yang signifikan.

Karang memiliki peran penting dalam ekosistem laut dan pentingnya peran zooxanthella untuk karang, oleh karena itu diharapkan penulis dan mahasiswa lainnya dapat menjaga lingkungan agar ekosistem terumbu karang tetap terjaga. Penelitian ini hanya menghitung densitas zooxanthella tanpa mengetahui jenisnya secara pasti, diharapkan untuk penelitian selanjutnya melakukan uji RNA untuk mengetahui Tipe zooxanthella yang ada pada karang.

\section{DAFTAR PUSTAKA}

1. Affandi, J. (2015). Analisis Densitas Zooxanthella pada Karang Acropora sp di Pulau Sironjong Gadang Kabupaten Pesisir Selatan Provinsi Sumatera Barat. Jurnal Online Mahasiswa Fakultas Perikanan dan Kelautan Universitas Riau, Pekanbaru. 2(1)

2. Ain, N.J. (2019). Pengaruh Perbedaan Intensitas Cahaya Terhadap Kelimpahan Zooxanthella pada Karang Acropora sp di Periaran Pulau Kasiak, Provinsi Sumatera Barat. Jurnal Online Mahasiswa Fakultas Perikanan dan Kelautan Universitas Riau, Pekanbaru. 6.

3. Asmiati., R.D. Palupi, dan Ira. (2017). Densitas Zooxhantella Berdasarkan Bentuk Pertumbuhan Karang di Perairan Kessilampe dan Bungkutoko Kendari. Jurnal Sapa Laut. 2(2) : 37-44.

4. Coremap. (2020). Pemutihan Karang (Bleaching Coral) dan Kejadian Bleaching Tahun 2016.

5. Costa, C.F., dan F.D. Amaral. (2000). Density and size differences of symbiotic dinoflagellates from five reef-buliding coral species from Brazil. Proceedings of the 6th International Coral Reef Symposium: 159-162.

6. Effendi, F.W dan Aunurrohim. (2012). Densitas Zooxanthella dan Pertumbuhan Karang Acropora Formosa dan Acropora Nobilis di Perairan Pembangkit Listrik Tenaga UAP 
(PLTU) Paiton, Probolinggo, Jawa Timur. Jurnal Jurusan Biologi, FMIPA. Institut Teknologi Sepuluh November : $1-7$.

7. Fachrurrozie, A. (2012). Pengaruh Perbedaan Intensitas Cahaya Terhadap Kelimpahan Zooxanthella pada Karang Branching dan Digitate di Perairan Pulau Pari, Kepulaauan Seribu. Skripsi. Universitas Indonesia, Depok.

8. Frananda, H., D. Chandra., dan F.M. Sari. (2019). Pemetaan Kondisi Tutupan Terumbu Karang di Kawasan Mandeh Kabupaten Pesisir Selatan Sumatera Barat. Jurnal Geografi, $8(1)$.

9. Gaffar, S., P.Z.N., \& Purwati, P. (2014). Preferensi mikrohabitat bintang laut perairan Pulau Hari, Sulawesi Tenggara. Jurnal Ilmu dan Teknologi Kelautan Tropis. 6(1) : 1-15

10. Ira. (2004). Studi Kepadatan Zooxanthella yang Berasosiasi dengan Kima (Tridacnidae) di Perairan Kepulauan Spermonde. Skripsi. Universitas Hasanuddin, Makassar.

11. Johan, O. (2007). Beberapa Genus Karang yang Umum di Indonesia. Terangi. Jakarta.

12. Keputusan Menteri Negara Lingkungan Hidup Nomor 51. (2004). Tentang Baku Mutu Air Laut. Menteri Negara Lingkungan Hidup.

13. Lakastri. L., P. W. Purnomo., dan M.R. Muskananfola. (2018). Pengaruh Kedalaman Terhadap Produktivitas Primer dan Densitas Zooxanthella pada Karang Dominan di Pulau Cemara Kecil, Karimunjawa. Journal of Maquares. 7(4) : 440-446.

14. Luthfi, O, M., dan P.T. Anugrah. (2017). Distribusi Karang Keras (Scleractinia) sebagai Penyusun Utama Ekosistem Terumbu Karang di Gosong Karang Pakiman, Pulau Bawean. Jurnal Ilmu-Ilmu Perairan, Pesisir dan Perikanan. 6(1): 9-22.

15. Manuputty, A. E. (2008). Beberapa Aspek Ekologi Oktokoral. Oseana 33(2) : 33-42.

16. Suharsono. (2010). Jenis-jenis Karang yang umum dijumpai di perairan Indonesia. P3OLIPI. Jakarta. $382 \mathrm{hlm}$.

17. Thamrin. (1994). Comparative study on the effect of hight temperature on Goniastrea aspera Verrill, Psammocora contiggue (Esper) and Stylophora pistillata (Esper). Master Thesis. University of Ryukyus Okinawa, Japan. 78 p.

18. Thamrin. (2017). Karang Biologi Reproduksi dan Ekologi. Minamandiri Press. Pekanbaru. 